\begin{tabular}{|c|c|c|c|}
\hline \multirow{3}{*}{$\begin{array}{r}\text { Case Reports in } \\
\text { Gastroenterology }\end{array}$} & \multirow{2}{*}{\multicolumn{2}{|c|}{ Case Rep Gastroenterol 2016;10:381-391 }} & \multirow[b]{3}{*}{$\begin{array}{l}\text { Karger } \\
\text { Open access }\end{array}$} \\
\hline & & & \\
\hline & $\begin{array}{l}\text { DOI: 10.1159/000448066 } \\
\text { Publisnea onine: July Z9, } 2016\end{array}$ & $\begin{array}{l}\text { (C) } 2016 \text { The Author(s) } \\
\text { Published by S. Karger AG, Basel } \\
\text { www.karger.com/crg }\end{array}$ & \\
\hline & $\begin{array}{l}\text { This article is licensed under } \\
\text { International License (CC BY- } \wedge \\
\text { Usage and distribution for comn }\end{array}$ & $\begin{array}{l}\text { nons Attribution-NonCommercial } 4.0 \\
\text { ger.com/Services/OpenAccessLicense). } \\
\text { uires written permission. }\end{array}$ & \\
\hline
\end{tabular}

\title{
Pseudocirrhosis: A Case Series and Literature Review
}

\author{
Abimbola Adike $^{a} \quad$ Nina Karlin ${ }^{b} \quad$ Christine Menias $^{c} \quad$ Elizabeth J. Carey $^{a}$ \\ ${ }^{a}$ Division of Gastroenterology and Hepatology, Mayo Clinic Arizona, Phoenix, Ariz., USA; \\ ${ }^{b}$ Division of Hematology and Oncology, Mayo Clinic Arizona, Phoenix, Ariz., USA; \\ 'Department of Radiology, Mayo Clinic Arizona, Phoenix, Ariz., USA
}

\section{Keywords}

Pseudocirrhosis · Metastatic cancer · Metastatic breast cancer $\cdot$ Portal hypertension

\begin{abstract}
Pseudocirrhosis describes morphological changes of the liver that closely mimic cirrhosis, without the typical histopathological changes seen in cirrhosis. It most commonly occurs in patients with metastatic breast cancer, although it has been reported in other malignancies as well. Like in cirrhosis, portal hypertension is often seen in patients with pseudocirrhosis. Pseudocirrhosis is a rare but important complication of metastatic cancer. In this case series and literature review, we describe 6 patients with hormone-receptor-positive metastatic breast cancer. We report the significant morbidity associated with pseudocirrhosis in the course of treatment in patients with metastatic breast cancer.

(C) 2016 The Author(s)

Published by S. Karger AG, Basel
\end{abstract}

\section{Introduction}

Malignant pseudocirrhosis is a rare but important complication of metastatic disease and is most commonly described in patients with breast cancer [1]. Although it radiologically and clinically mimics cirrhosis, the pathophysiology of pseudocirrhosis is distinct from that of cirrhosis and includes: response of hepatic tumors to chemotherapy resulting in scarring and capsular retraction of the liver parenchyma; desmoplastic reaction surrounding 
infiltrating hepatic metastatic masses with altered expression of cell adhesion molecules, and nodular regenerative hyperplasia in response to ischemia from chemotherapy-induced hepatic injury [1-3]. Patients with pseudocirrhosis most commonly present with complications from portal hypertension. Herein, we perform a review of reported cases of pseudocirrhosis in the literature and present 6 patients from our institution with metastatic breast cancer who developed pseudocirrhosis during the clinical course of breast cancer treatment.

\section{Case Presentations}

\section{Case 1}

A 46-year-old woman was initially diagnosed with ER-positive, PR-positive breast cancer. She received neoadjuvant chemotherapy with Adriamycin and cyclophosphamide, and then underwent lumpectomy with axillary node dissection; six of twelve nodes were positive for malignancy. Postoperatively, she underwent two additional cycles of Adriamycin and cyclophosphamide followed by radiation. After radiation, tamoxifen was given for 5 years. Twelve years after the initial diagnosis, she presented with back pain and was found to have metastatic breast cancer to the spine and pelvis. She underwent radiation treatment to the lumbosacral spine and was treated with several chemotherapeutic agents as shown in table 1. However, metastatic disease to the liver, lungs, and pleura occurred and she developed ascites requiring monthly paracentesis. Laboratory data showed alanine aminotransferase (ALT) $52 \mu / \mathrm{l}$, aspartate aminotransferase (AST) $138 \mu / \mathrm{l}$, alkaline phosphatase (ALP) $814 \mu / \mathrm{l}$, total bilirubin (TB) $1.1 \mathrm{mg} / \mathrm{dl}$, international normalized ratio (INR) 0.98 , albumin $2.6 \mathrm{~g} / \mathrm{dl}$, creatinine $0.8 \mathrm{mg} / \mathrm{dl}$ and platelets $135 \times 10^{9} / \mathrm{l}$. CT of the abdomen and pelvis revealed a shrunken liver with a nodular contour and innumerable low-attenuation nodules consistent with metastatic disease and moderate abdominal ascites. Due to poor prognosis and functional status, hospice was recommended and the patient died several weeks later.

\section{Case 2}

A 65-year-old woman was diagnosed with an ER-positive, PR-positive, her-2/neu normal infiltrating ductal adenocarcinoma of the right breast. A right mastectomy was performed; pathology revealed a 5-cm tumor with 1 of 2 lymph nodes positive. She then underwent adjuvant chemotherapy with docetaxel and cyclophosphamide, followed by radiation treatment. Adjuvant therapy with anastrozole was started. Two years later, she was found to have an abnormal PET CT scan, prompting workup that revealed metastatic ER-positive, PRpositive, her-2/neu normal breast adenocarcinoma to the bone. Fulvestrant was started. Because of progressive metastatic disease to the bone, pleura, lungs, liver, spleen and lymph nodes, hormonal therapy was subsequently discontinued (fig. 1).

Several therapeutic regimens were employed, but the disease progressed despite these agents. Finally, capecitabine was initiated with resultant decrease in tumor markers. Surveillance imaging reported nodular changes in the liver, with ascites and paraesophageal varices (fig. 2). There was no evidence of splenomegaly. On examination, she had ascites and peripheral edema.

As a result of pseudocirrhosis as identified on imaging, the decision was made to stop systemic chemotherapy and re-initiate therapy with hormonal and targeted therapy with exemestane and everolimus. Laboratory data showed ALT $46 \mu / \mathrm{l}$, AST $70 \mu / \mathrm{l}$, ALP $329 \mu / \mathrm{l}$, TB $0.6 \mathrm{mg} / \mathrm{dl}$, INR 1.16 , albumin $3.3 \mathrm{~g} / \mathrm{dl}$, creatinine $0.8 \mathrm{mg} / \mathrm{dl}$ and platelets $116 \times 10^{9} / \mathrm{l}$. The patient was initiated on furosemide and spironolactone. She underwent upper endoscopy 
that revealed grade 1 esophageal varices, small type 1 gastric varices and portal hypertensive gastropathy (fig. 3). Anticoagulation for history of deep vein thrombosis and pulmonary emboli was stopped to decrease the potential severity of a bleeding varix. Nadolol was started as primary prophylaxis for variceal bleeding.

Although the ascites and peripheral edema responded to diuretic therapy, a decline in performance status led to transition to hospice, and the patient died 1 month later.

Case 3

A 66-year-old woman was diagnosed with stage IIa ER-positive, PR-positive, her-2/neu normal invasive ductal carcinoma of the left breast. She underwent mastectomy, followed by chemotherapy with docetaxel and cyclophosphamide and adjuvant radiation therapy. She was then placed on adjuvant aromatase inhibitor therapy, but was intolerant to exemestane, anastrozole and letrozole. Three years following the initial diagnosis, a $4.2-\mathrm{cm}$ infiltrative lesion in the S1 vertebrae was found. She was treated with fulvestrant and palliative radiation. Five months after the diagnosis of osseous metastasis, hepatic metastases were noted. Systemic chemotherapy with several agents was used because of progressive disease (table 1). CT of the abdomen showed multiple hepatic lesions with necrosis, linear fibrotic bands within the parenchyma and capsular nodularity consistent with pseudocirrhosis. In addition, there was splenomegaly of $14 \mathrm{~cm}$ and moderate ascites. No appreciable varices were seen on imaging. Several months later, abdominal distention with ascites requiring paracentesis developed. She was initiated on diuretic therapy with furosemide and spironolactone. Although the metastatic disease stabilized, liver function worsened: ALT $121 \mu / \mathrm{l}$, AST $395 \mu / \mathrm{l}$, ALP $1,233 \mu / \mathrm{l}$, and TB $4.3 \mathrm{mg} / \mathrm{dl}$. A pleural catheter was placed for malignant ascites refractory to diuretics, and the patient died several weeks later.

\section{Case 4}

A 60-year-old woman presented with metastatic breast cancer with osseous involvement. She had been diagnosed at the age of 39 years with ER-positive, PR-positive, her$2 /$ neu normal invasive ductal carcinoma of the left breast. She was treated with adjuvant 5 FU, Adriamycin and cyclophosphamide, followed by tamoxifen for 5 years, and then letrozole for 5 years. Three years after completion of letrozole, widespread osseous metastasis was found and denosumab and exemestane were started. Despite several chemotherapeutic regimens, the disease progressed to include mediastinal involvement and she was initiated on eribulin via a clinical trial and responded well initially. However, after eight cycles, hepatic metastasis was found. Eribulin was discontinued, and gemcitabine was started. Subsequently, the patient was found to have elevated liver function tests: ALT $120 \mu / \mathrm{l}$, AST $413 \mu / \mathrm{l}$, ALP $764 \mu / \mathrm{l}$ and TB $8.7 \mathrm{mg} / \mathrm{dl}$; platelets $90 \times 10^{9} / \mathrm{l}$, creatinine $0.6 \mathrm{mg} / \mathrm{dl}$, sodium $125 \mathrm{mmol} / \mathrm{l}$ and albumin $2.2 \mathrm{~g} / \mathrm{dl}$. An MRI of the abdomen was remarkable for multiple metastatic hepatic lesions with diffuse hepatic enlargement and capsular retraction. No collateral veins or splenomegaly were observed. Hospice was recommended, and the patient died several days later.

\section{Case 5}

A 76-year-old woman with history of stage II, ER-positive, PR-positive, her-2/neu normal, invasive ductal adenocarcinoma of the right breast underwent lumpectomy and radiation treatment. She was then started on anastrozole. Three years after the initial diagnosis, ER-positive, PR-positive osteosclerotic lesions of T7 and T11 vertebrae were found. She underwent palliative radiation treatment of the osseous lesions, and was placed on fulvestrant, 
which did not lead to any significant change in disease. Eight months later, fulvestrant was discontinued because of progressive disease and the patient was started on tamoxifen. Several months after initiation of tamoxifen, she was found to have hepatic lesions, which prompted initiation of paclitaxel. After completing 8 cycles of paclitaxel, she was found to have elevated liver enzymes with normal synthetic function: ALT $61 \mu / \mathrm{l}$, AST $66 \mu / \mathrm{l}$, ALP 315 $\mu / \mathrm{l}$ and TB $0.3 \mathrm{mg} / \mathrm{dl}$; platelets $134 \times 10^{9} / \mathrm{l}$, creatinine $0.9 \mathrm{mg} / \mathrm{dl}$, INR 1.08 and albumin 3.7 $\mathrm{g} / \mathrm{dl}$. CT of the abdomen revealed pseudocirrhosis, with heterogenous enhancement and extensive ill-defined nodularity suspicious for metastatic disease with moderate ascites. There were no appreciable varices or splenomegaly. A chemotherapy holiday was necessitated in the setting of progressive weakness and worsening elevated liver function tests, with TB peaking at $3.7 \mathrm{mg} / \mathrm{dl}$. The patient requested hospice and died shortly thereafter.

Case 6

A 64-year-old woman was diagnosed with locally advanced 4-cm right breast ERnegative, PR-negative, her-2/neu overexpressed infiltrating ductal carcinoma. She received neoadjuvant chemotherapy with docetaxel, carboplatin and trastuzumab. She then underwent right mastectomy with reconstruction and completed 1 year of trastuzumab therapy. Three years later, the patient presented with abdominal distention and jaundice. Laboratory values included platelets $329 \times 10^{9} / \mathrm{l}$, ALP $788 \mu / \mathrm{l}$, ALT $143 \mu / \mathrm{l}$, AST $332 \mu / \mathrm{l}$, TB 2 mg/dl and albumin $3.2 \mathrm{~g} / \mathrm{dl}$. CT of the abdomen revealed ascites and multiple hepatic lesions concerning for metastasis.

An ultrasound-guided liver biopsy showed metastatic adenocarcinoma, consistent with ER-negative, PR-negative, her-2/neu overexpressed breast cancer (fig. 4). At this time, the patient was initiated on ado-trastuzumab emtansine (TDM-1). In addition, furosemide was added for recurrent ascites and peripheral edema. Surveillance CT of the abdomen obtained 2 months after initiation of TDM-1 showed interval progression of pseudocirrhosis with linear areas of fibrous bands in the parenchyma with capsular nodularity and atrophy of the right and left hepatic lobes. Splenomegaly of $13 \mathrm{~cm}$ and small paraesophageal varices were also noted (fig. 5). The patient completed five cycles on ado-trastuzumab emtansine and was noted to have a decrease in the size and number of hepatic metastasis with a more atrophic liver with markedly nodular contour.

Upper endoscopy was performed for acute hematemesis, revealing esophageal varices that were treated with banding. Eventually, as a result of progressive disease, she was started on pertuzumab, trastuzumab and gemcitabine and then proceeded with maintenance therapy on pertuzumab and trastuzumab. Laboratory values included platelets $78 \times 10^{9} / \mathrm{l}$, ALP $162 \mu / \mathrm{l}$, ALT $71 \mu / \mathrm{l}$, AST $63 \mu / \mathrm{l}$, TB $0.5 \mathrm{mg} / \mathrm{dl}$ and albumin $4.1 \mathrm{~g} / \mathrm{dl}$.

After eight cycles of maintenance therapy with pertuzumab and trastuzumab, CT of the abdomen (fig. 6) showed stable findings of pseudocirrhosis with atrophy and capsular nodularity of the right and left hepatic lobes, without any discrete hepatic lesions or ascites. Splenomegaly of $14 \mathrm{~cm}$ was also noted with paraesophageal varices. Her functional status continues to be excellent 18 months following the initial diagnosis.

\section{Discussion}

Pseudocirrhosis is a radiological diagnosis describing diffuse hepatic nodularity without histopathological confirmation of cirrhosis. It is defined by morphological changes that mimic cirrhosis including capsular retraction, nodularity, parenchyma atrophy and caudate lobe 
hypertrophy [4, 5]. A review of the English-language literature from 1975 to 2015 revealed 18 publications describing this entity in patients with malignancy (table 2). Although breast cancer with liver metastasis treated with chemotherapy is the most commonly reported cause of pseudocirrhosis, it has also been reported in association with other metastatic diseases, including pancreatic cancer, colon cancer, medullary thyroid cancer and esophageal cancer [3, 6-9]. Our case series and review of the literature highlights the significant morbidity associated with pseudocirrhosis (table 2 ).

The pathophysiology of pseudocirrhosis is posited to be multifactorial, including (1) response of hepatic tumors to chemotherapy resulting in scarring and capsular retraction, (2) fibrosis surrounding infiltrating hepatic metastatic masses, and (3) nodular regenerative hyperplasia in response to ischemia from chemotherapy-induced hepatic injury [2, 3, 5]. Both regression as a response to chemotherapy of hepatic metastasis and progression with fibrosis surrounding the infiltrating hepatic tumors are associated with pseudocirrhosis [3, 10]. Sinusoidal obstruction with venous obstruction as a result of chemotherapy is another proposed mechanism. In our case series, 1 patient had a liver biopsy that showed infiltration of malignant cells into the liver prior to the diagnosis of pseudocirrhosis on imaging.

Although pseudocirrhosis has been reported in other malignancies, the relationship between hormone-receptor-positive breast cancer and pseudocirrhosis is unclear. A case series by Sonnenblick et al. [11] of 5 patients with breast cancer and hepatic metastasis showed that 4 of these patients had hormone-receptor-positive breast cancer, and 1 patient had HER2-receptor-positive disease. Five of our patients had ER/PR-positive breast cancer, and 1 had HER2 overexpression; and all had been treated with hormonal therapy during the disease course. It is also unclear which chemotherapeutic agents can worsen pseudocirrhosis. No particular chemotherapeutic agent has been identified as sole culprit. Several agents, including capecitabine, gemcitabine, trastuzumab and paclitaxel, have been associated with pseudocirrhosis $[4,12]$. No clinical significance between capsular retraction and chemotherapeutic regimen or hormone-receptor status was found in a retrospective review of 29 patients with breast cancer with hepatic metastasis [10].

While some patients may be asymptomatic, with pseudocirrhosis identified incidentally on surveillance imaging, many patients typically present with complications that arise from portal hypertension (table 2). Abdominal distention with ascites was the most common initial presentation of patients from the literature review (table 2) as well as in our case series. The prevalence of portal hypertension in pseudocirrhosis is not known. In 2007, a retrospective study by Qayyum et al. [5] of 91 patients undergoing chemotherapy for breast cancer with hepatic metastasis over a median follow-up period of 15 months showed that about $75 \%$ of these patients developed hepatic contour abnormalities. Of these, 6 of 16 patients with diffuse nodularity and 1 of 42 patients with limited contraction developed portal hypertension. In our review of reported cases in the literature (table 2), all but 1 patient did not have a reported complication from portal hypertension [9], and one case series did not describe this [10]. In our case series of 6 patients, 5 had signs of portal hypertension including ascites $(n=5)$, splenomegaly $(n=2)$, esophageal/gastric varices $(n=2)$ and a variceal bleed $(\mathrm{n}=1)$.

It is important to recognize pseudocirrhosis early as it can be associated with complications of portal hypertension, rapid progression to liver failure and increased morbidity in patients with metastatic cancer. Our case series supports the stance in the current literature that pseudocirrhosis is associated with increased morbidity and mortality - 5 of our 6 patients died within weeks to months (range 1-24 weeks, median 22 weeks) following the diagnosis of pseudocirrhosis on imaging (table 1 ). 


\section{Conclusion}

Pseudocirrhosis is a radiological term used to describe the development of diffuse hepatic nodularity in the setting of hepatic metastases treated with chemotherapy. While it has been described in multiple types of cancer, it is most common in patients with breast cancer. Pseudocirrhosis is a potentially lethal complication of metastatic breast cancer, and further studies are urgently needed to better understand and prevent this devastating complication.

\section{Statement of Ethics}

The authors have no ethical conflicts to declare.

\section{Disclosure Statement}

The authors have no conflicts of interest.

\section{References}

-1 Jüngst C, Krämer J, Schneider G, Lammert F, Zimmer V: Subacute liver failure by pseudocirrhotic metastatic breast cancer infiltration. Ann Hepatol 2013;12:834-836.

2 Sass DA, Clark K, Grzybicki D, Rabinovitz M, Shaw-Stiffel TA: Diffuse desmoplastic metastatic breast cancer simulating cirrhosis with severe portal hypertension: a case of 'pseudocirrhosis'. Dig Dis Sci 2007;52:749-752.

-3 Lee SL, Chang ED, Na SJ, et al: Pseudocirrhosis of breast cancer metastases to the liver treated by chemotherapy. Cancer Res Treat 2014;46:98-103.

4 Jeong WK, Choi S-Y, Kim J: Pseudocirrhosis as a complication after chemotherapy for hepatic metastasis from breast cancer. Clin Mol Hepatol 2013;19:190-194.

5 Qayyum A, Lee GK, Yeh BM, Allen JN, Venook AP, Coakley FV: Frequency of hepatic contour abnormalities and signs of portal hypertension at CT in patients receiving chemotherapy for breast cancer metastatic to the liver. Clin Imaging 2007;31:6-10.

6 Kang SP, Taddei T, McLennan B, Lacy J: Pseudocirrhosis in a pancreatic cancer patient with liver metastases: a case report of complete resolution of pseudocirrhosis with an early recognition and management. World J Gastroenterol 2008;14:1622-1624.

7 Kobashigawa C, Nakamoto M, Hokama A, Hirata T, Kinjo F, Fujita J: Pseudocirrhosis in metastatic esophageal cancer. South Med J 2010;103:488-489.

8 Harry BL, Smith ML, Burton JR Jr, Dasari A, Eckhardt SG, Diamond JR: Medullary thyroid cancer and pseudocirrhosis: case report and literature review. Curr Oncol 2012;19:e36-e41.

-9 Battisti S, Guida FM, Pagliara E, Tonini G, Zobel BB, Santini D: Pseudocirrhosis after anti-EGFR-based neoadjuvant therapy for hepatic metastasis from colon cancer: a different point of view. Clin Colorectal Cancer 2014;13:e13-e15.

10 Fennessy FM, Mortele KJ, Kluckert T, Gogate A, Ondategui-Parra S, Ros P, Silverman SG: Hepatic capsular retraction in metastatic carcinoma of the breast occurring with increase or decrease in size of subjacent metastasis. AJR Am J Roentgenol 2004;182:651-655.

11 Sonnenblick A, Appelbaum L, Peretz T: Liver failure on the background of pseudocirrhosis in patients with liver metastasis from breast cancer, who responded to treatment. Onkologie 2011;34:199-201.

12 Ngo D, Jia JB, Green CS, Gulati AT, Lall C: Cancer therapy related complications in the liver, pancreas, and biliary system: an imaging perspective. Insights Imaging 2015;6:665-677.

13 Chandrakar V, Isaacs C: Breast cancer-related pseudocirrhosis and esophageal varices. Breast J 2005;11:301-302.

14 Young ST, Paulson EK, Washington K, Gulliver DJ, Vredenburgh JJ, Baker ME: CT of the liver in patients with metastatic breast cancer treated by chemotherapy: findings simulating cirrhosis. AJR Am J Roentgenol 1994;163:1385-1388.

15 Nascimento AB, Mitchell DG, Rubin R, Weaver E: Diffuse desmoplastic breast carcinoma metastases to the liver simulating cirrhosis at MR imaging: report of two cases. Radiology 2001;221:117-121. 
Adike et al.: Pseudocirrhosis: A Case Series and Literature Review

\footnotetext{
16 Leyden JE, Looby S, Gulmann C, Patchett SE: Cryptogenic cirrhosis: or is it? An unusual case of portal hypertension. Gut 2010;59:1206.

17 Liu CH, Chao TY: Education and imaging. Hepatobiliary and pancreatic: Pseudocirrhosis after chemotherapy. J Gastroenterol Hepatol 2011;26:788.

-18 Fournier C, Tisman G, Kleinman R, Park Y, Macdonald WD: Clinical evidence for overcoming capecitabine resistance in a woman with breast cancer terminating in radiologically occult micronodular pseudo-cirrhosis with portal hypertension: a case report. J Med Case Rep 2010;4:112.

19 Borja ER, Hori JM, Pugh RP: Metastatic carcinomatosis of the liver mimicking cirrhosis: case report and review of the literature. Cancer 1975;35:445-449.
}
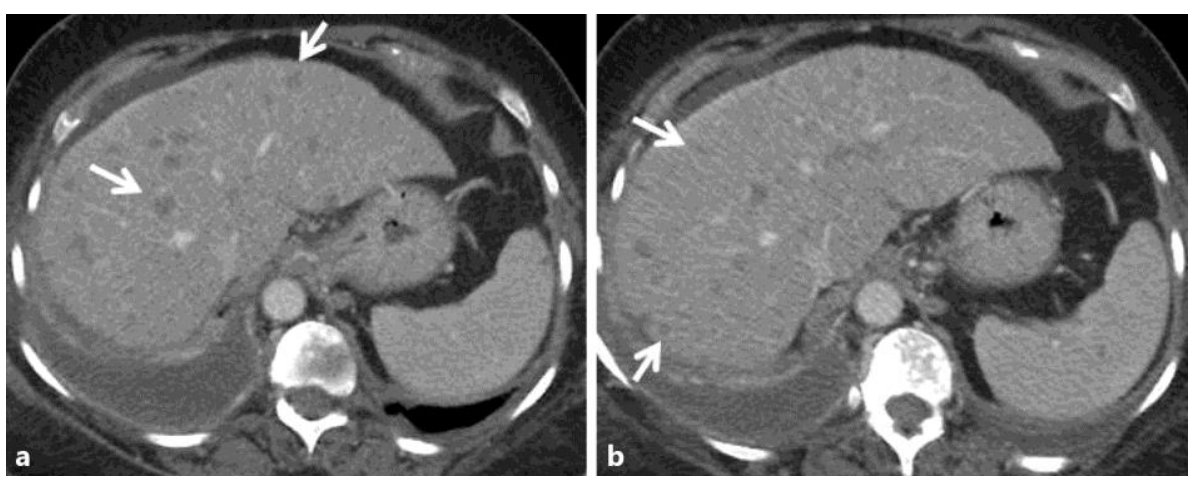

Fig. 1. Case 2: a 65-year-old woman with ER/PR(+) infiltrating ductal adenocarcinoma of the right breast. Contrast-enhanced axial CT images 2 years following mastectomy and adjuvant chemoradiation (a, b) show an enlarged fatty liver with several small hypodense round masses in both the right and left hepatic lobes corresponding to diffuse metastatic disease (white arrows in $\mathbf{a}, \mathbf{b}$ ).
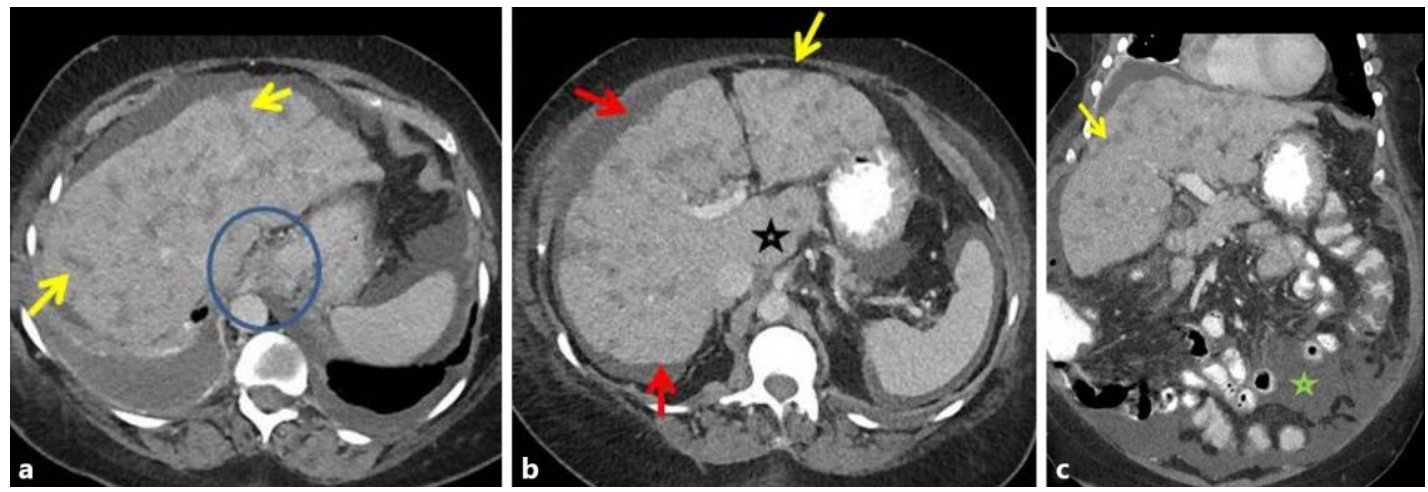

Fig. 2. Case 2: follow-up contrast-enhanced CT in the same patient 6 months after initiation of paclitaxel and gemcitabine, followed by vinorelbine, ixabepilone and capecitabine showed features of pseudocirrhosis. Contrast-enhanced axial (a, b) and coronal (c) images show several ill-defined, somewhat linear, 'bandlike' masses that extend to the periphery of the liver (yellow arrows in $\mathbf{a}-\mathbf{c}$ ). There is secondary capsular retraction and nodularity of the liver surface (red arrows in a, b) and an enlarged caudate lobe (black star in b). Changes of portal hypertension are present with paraesophageal varices (blue circle in a) and new ascites (green star in c). 


\begin{tabular}{|c|c|c|}
\hline \multirow{2}{*}{$\begin{array}{l}\text { Case Reports in } \\
\text { Gastroenterology }\end{array}$} & \multicolumn{2}{|c|}{ Case Rep Gastroenterol 2016;10:381-391 } \\
\hline & $10.1159 / 000448066$ & $\begin{array}{l}\text { O } 2016 \text { The Author(s). Published by S. Karger AG, Basel } \\
\text { www.karger.com/crg }\end{array}$ \\
\hline
\end{tabular}
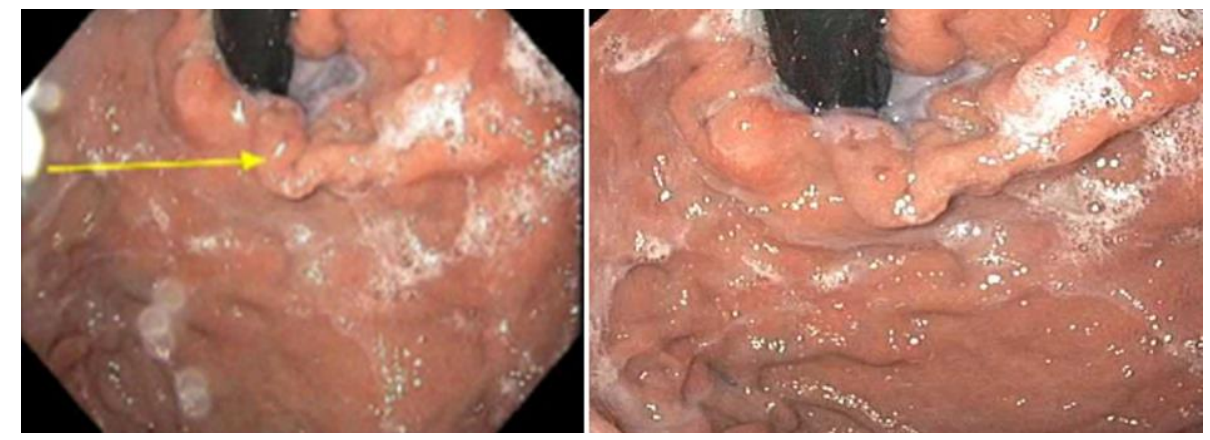

Fig. 3. Upper endoscopy revealed type 1 gastric varices.
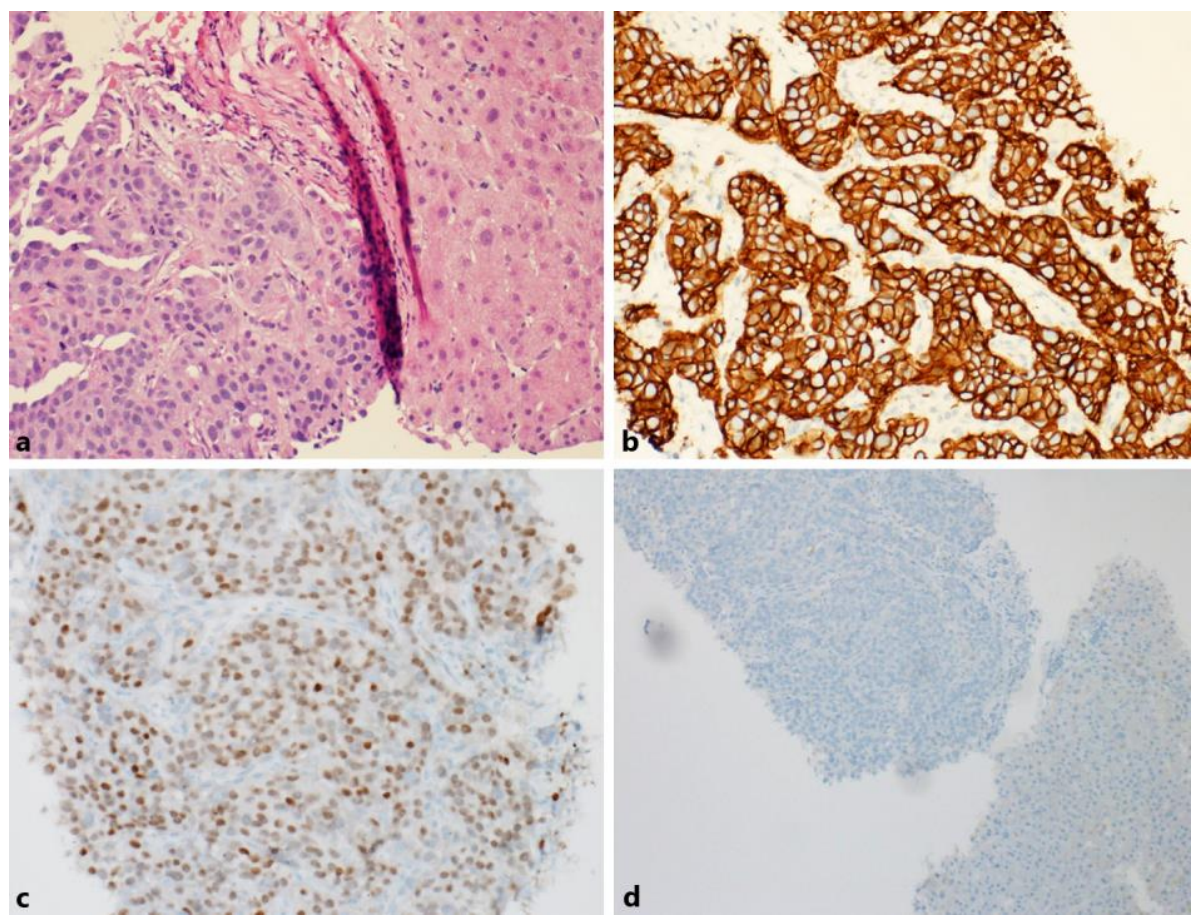

Fig. 4. a Fine needle aspiration biopsy of the liver normal parenchyma of the liver (right) with tumor infiltration with malignant cells (left). $\times 200$. b, c Immunohistochemical staining of the liver tumor shows positive staining for Her2 $3+(\times 200)$ and positive staining for GATA-3 $(\times 200)$. $\mathbf{d}$ Negative control for Her2 and GATA. $\times 100$. 

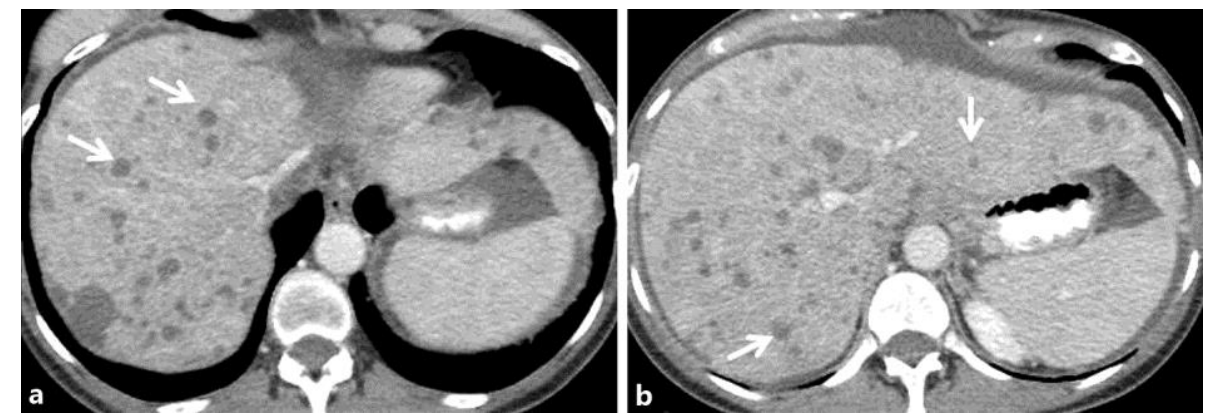

Fig. 5. Case 6: a 64-year-old woman with locally advanced ER/PR(-), HER 2(+) infiltrating, ductal carcinoma, treated with neoadjuvant chemotherapy with docetaxel, carboplatin and trastuzumab, subsequent mastectomy and adjuvant trastuzumab. Contrast-enhanced axial CT images show multiple small round hypodense masses in both the right and left hepatic lobes consistent with hepatic metastases (white arrows $\mathbf{a}, \mathbf{b})$.
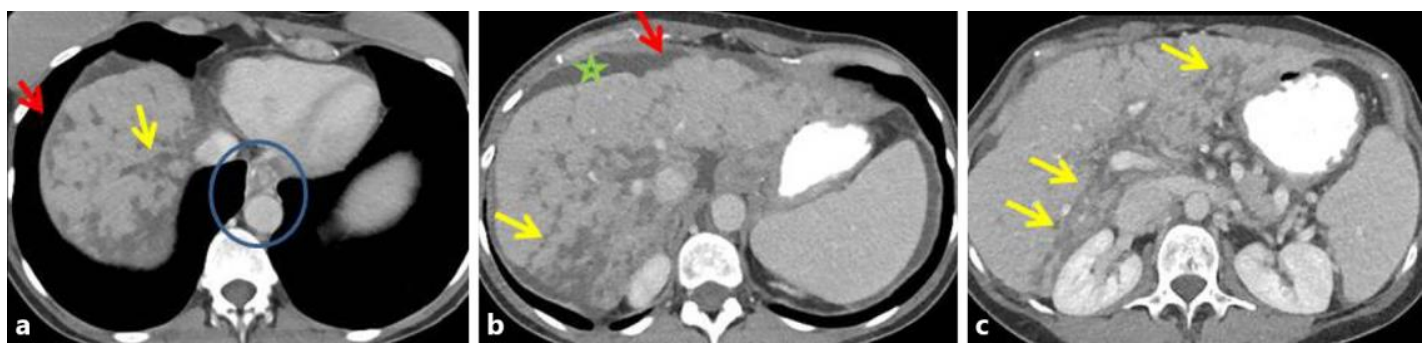

Fig. 6. Case 6: follow-up contrast-enhanced CT 3 months after initiation of ado-trastuzumab emtansine showed features of pseudocirrhosis. Contrast-enhanced axial (a-c) CT images show interval atrophy of both the right and left hepatic lobes, with diffuse surface nodularity (red arrows in a, b). Ill-defined, linear, 'band like' masses that extend to the periphery of the liver (yellow arrows in a-c) correspond to bands of fibrosis. Changes of portal hypertension are present with splenomegaly, paraesophageal varices (blue circle in a) and new ascites (green star in $\mathbf{b}$ ). 
Table 1. Summary of clinical presentation of 6 patients with pseudocirrhosis

\begin{tabular}{|c|c|c|c|c|c|c|c|}
\hline Case & $\begin{array}{l}\text { Age }^{\text {a }} \\
\text { years }\end{array}$ & $\begin{array}{l}\text { Type of } \\
\text { malignancy }\end{array}$ & $\begin{array}{l}\text { Site of } \\
\text { metastasis }\end{array}$ & Chemotherapy regimen & $\begin{array}{l}\text { Signs of portal } \\
\text { hypertension }\end{array}$ & Status & $\begin{array}{l}\text { Time between } \\
\text { diagnosis and } \\
\text { death, weeks }\end{array}$ \\
\hline 1 & 60 & $\begin{array}{l}\text { ER-positive, } \\
\text { PR-positive breast } \\
\text { cancer }\end{array}$ & $\begin{array}{l}\text { Liver, CNS, } \\
\text { bone, lungs, } \\
\text { pleura and } \\
\text { lymph nodes }\end{array}$ & $\begin{array}{l}\text { Adriamycin, cyclophospha- } \\
\text { mide, tamoxifen, paclitaxel, } \\
\text { bevacizumab, gemcitabine, } \\
\text { vinorelbine, ixabepilone, } \\
\text { capecitabine, fulvestrant } \\
\text { and eribulin }\end{array}$ & Refractory ascites & Deceased & 22 \\
\hline 2 & 70 & $\begin{array}{l}\text { ER-positive, PR- } \\
\text { positive, HER-2/neu } \\
\text { negative breast } \\
\text { cancer }\end{array}$ & $\begin{array}{l}\text { Liver, bone, } \\
\text { lungs, pleura, } \\
\text { lymph nodes } \\
\text { and spleen }\end{array}$ & $\begin{array}{l}\text { Docetaxel, cyclophospha- } \\
\text { mide, anastrozole, fulves- } \\
\text { trant, paclitaxel, gemcitabine, } \\
\text { vinorelbine, ixabepilone, } \\
\text { capecitabine, exemestane } \\
\text { and everolimus }\end{array}$ & $\begin{array}{l}\text { Ascites, peripheral } \\
\text { edema, esophageal } \\
\text { and gastric varices, } \\
\text { portal gastropathy }\end{array}$ & Deceased & 24 \\
\hline 3 & 66 & $\begin{array}{l}\text { ER-positive, PR- } \\
\text { positive, HER-2/neu } \\
\text { negative breast } \\
\text { cancer }\end{array}$ & Liver, bone & $\begin{array}{l}\text { Docetaxel, cyclophospha- } \\
\text { mide, fulvestrant, paclitaxel, } \\
\text { gemcitabine, capecitabine } \\
\text { and ixabepilone }\end{array}$ & $\begin{array}{l}\text { Ascites, } \\
\text { splenomegaly }\end{array}$ & Deceased & 23 \\
\hline 4 & 60 & $\begin{array}{l}\text { ER-positive, PR- } \\
\text { positive, HER-2/neu } \\
\text { negative breast } \\
\text { cancer }\end{array}$ & $\begin{array}{l}\text { Liver, bone, } \\
\text { adrenal glands, } \\
\text { lymph nodes }\end{array}$ & $\begin{array}{l}\text { 5-FU, Adriamycin, cyclophos- } \\
\text { phamide, tamoxifen, letro- } \\
\text { zole, exemestane, everolimus, } \\
\text { fulvestrant, anastrozole, } \\
\text { capecitabine, eribulin and } \\
\text { gemcitabine }\end{array}$ & None & Deceased & 15 \\
\hline 5 & 81 & $\begin{array}{l}\text { ER-positive, PR- } \\
\text { positive, HER-2/neu } \\
\text { negative breast } \\
\text { cancer }\end{array}$ & Liver, bone & $\begin{array}{l}\text { Anastrozole, fulvestrant, } \\
\text { tamoxifen and paclitaxel }\end{array}$ & Ascites & Deceased & 1 \\
\hline 6 & 66 & $\begin{array}{l}\text { ER-negative, PR- } \\
\text { negative, HER-2/neu } \\
\text { overexpression }\end{array}$ & Liver, lungs & $\begin{array}{l}\text { Docetaxel, carboplatin, } \\
\text { trastuzumab, ado- } \\
\text { trastuzumab emtansine, } \\
\text { pertuzumab and gemcitabine }\end{array}$ & $\begin{array}{l}\text { Ascites, bleeding } \\
\text { esophageal varices, } \\
\text { peripheral edema, } \\
\text { and splenomegaly }\end{array}$ & Alive & $\mathrm{n} / \mathrm{a}$ \\
\hline
\end{tabular}

a Current age or at time of death. CNS = Central nervous system; $\mathrm{n} / \mathrm{a}=$ not applicable. 
Table 2. A summary of reported pseudocirrhosis cases in the literature

\begin{tabular}{|c|c|c|c|c|}
\hline Article & $\begin{array}{l}\text { Cases, } \\
\mathrm{n}\end{array}$ & Malignancy & $\begin{array}{l}\text { Portal hypertension } \\
\text { complication }\end{array}$ & Status \\
\hline $\begin{array}{l}\text { Battisti et al. [9], } \\
2014\end{array}$ & 1 & Colon cancer & None & Unknown \\
\hline $\begin{array}{l}\text { Lee et al. [3], } \\
2014\end{array}$ & 1 & Breast cancer & Bleeding esophageal varices, ascites & Deceased \\
\hline $\begin{array}{l}\text { Jüngst et al. [1], } \\
2013\end{array}$ & 1 & Breast cancer & $\begin{array}{l}\text { Bleeding esophageal varices, ascites and } \\
\text { hepatic encephalopathy }\end{array}$ & Deceased \\
\hline $\begin{array}{l}\text { Jeong et al. [4], } \\
2013\end{array}$ & 2 & Breast cancer & Ascites $(n=2)$ & $\begin{array}{l}\text { Deceased } \\
(\mathrm{n}=2)\end{array}$ \\
\hline $\begin{array}{l}\text { Harry et al. [8], } \\
2012\end{array}$ & 1 & $\begin{array}{l}\text { Medullary thyroid } \\
\text { cancer }\end{array}$ & $\begin{array}{l}\text { Ascites, esophageal varices, portal } \\
\text { hypertensive gastropathy }\end{array}$ & Deceased \\
\hline $\begin{array}{l}\text { Sonneblick et al. [11], } \\
2011\end{array}$ & 5 & Breast cancer & $\begin{array}{l}\text { Ascites }(n=5) \text {, hepatic encephalopathy } \\
(n=1) \text {, bleeding esophageal varices }(n=1)\end{array}$ & $\begin{array}{l}\text { Deceased } \\
(\mathrm{n}=5)\end{array}$ \\
\hline $\begin{array}{l}\text { Leyden et al. [16], } \\
2010\end{array}$ & 1 & Breast cancer & Ascites $(n=1)$, esophageal varices $(n=1)$ & Unknown \\
\hline $\begin{array}{l}\text { Liu and Chao. [17], } \\
2011\end{array}$ & 1 & Breast cancer & Ascites & Unknown \\
\hline $\begin{array}{l}\text { Kobashigawa et al. [7], } \\
2010\end{array}$ & 1 & Esophageal cancer & Ascites & Deceased \\
\hline $\begin{array}{l}\text { Fournier et al. [18], } \\
2010\end{array}$ & 1 & Breast cancer & Ascites, esophageal varices, splenomegaly & $\begin{array}{l}\text { Hospice, } \\
\text { unknown }\end{array}$ \\
\hline $\begin{array}{l}\text { Kang et al. [6], } \\
2008\end{array}$ & 1 & Pancreatic cancer & Ascites, peripheral edema & Unknown \\
\hline $\begin{array}{l}\text { Qayyum et al. [5], } \\
2007\end{array}$ & 68 & Breast cancer & $\begin{array}{l}\text { Ascites, portosystemic collateral veins or } \\
\text { splenomegaly }(n=7)\end{array}$ & Unknown \\
\hline Sass et al. [2], 2007 & 1 & Breast cancer & Ascites, bleeding esophageal varices & Deceased \\
\hline $\begin{array}{l}\text { Chandrakar and } \\
\text { Isaacs [13], } 2005\end{array}$ & 1 & Breast cancer & Ascites, bleeding esophageal varices & Unknown \\
\hline $\begin{array}{l}\text { Fennessy et al. [10], } \\
2004\end{array}$ & 29 & Breast cancer & Not described & Unknown \\
\hline $\begin{array}{l}\text { Nascimento et al. [15], } \\
2001\end{array}$ & 2 & Breast cancer & $\begin{array}{l}\text { Ascites }(n=2) \text {, peripheral edema }(n=2), \\
\text { splenomegaly }(n=1) \text {, encephalopathy }(n=1) \text {, } \\
\text { varices }(n=2)\end{array}$ & $\begin{array}{l}\text { Deceased } \\
(n=2)\end{array}$ \\
\hline $\begin{array}{l}\text { Young et al. [14], } \\
1994\end{array}$ & 22 & Breast cancer & $\begin{array}{l}\text { Ascites }(n=12) \text {, splenomegaly }(n=6) \\
\text { varices }(n=1)\end{array}$ & Unknown \\
\hline $\begin{array}{l}\text { Borja et al. [19], } \\
1975\end{array}$ & 1 & Breast cancer & $\begin{array}{l}\text { Ascites, splenomegaly and bleeding } \\
\text { esophageal varices }\end{array}$ & Deceased \\
\hline
\end{tabular}

